\title{
Historical and Archaeological Resources of Riverdale, A Company Town in Goliad County, Texas
}

John W. Clark Jr.

Follow this and additional works at: https://scholarworks.sfasu.edu/ita

Part of the American Material Culture Commons, Archaeological Anthropology Commons, Environmental Studies Commons, Other American Studies Commons, Other Arts and Humanities Commons, Other History of Art, Architecture, and Archaeology Commons, and the United States History Commons

Tell us how this article helped you.

This Article is brought to you for free and open access by the Center for Regional Heritage Research at SFA ScholarWorks. It has been accepted for inclusion in Index of Texas Archaeology: Open Access Gray Literature from the Lone Star State by an authorized editor of SFA ScholarWorks. For more information, please contact cdsscholarworks@sfasu.edu. 


\section{Historical and Archaeological Resources of Riverdale, A Company Town in Goliad County, Texas}

\section{Licensing Statement}

This is a work for hire produced for the Texas Department of Transportation (TxDOT), which owns all rights, title, and interest in and to all data and other information developed for this project under its contract with the report producer. The report may be cited and brief passages from this publication may be reproduced without permission provided that credit is given to TxDOT and the firm that produced it. Permission to reprint an entire chapter, section, figures or tables must be obtained in advance from the Supervisor of the Archeological Studies Branch, Environmental Affairs Division, Texas Department of Transportation, 125 East 11th Street, Austin, Texas, 78701. 
HISTORICAL AND ARCHAEOLOGICAL RESOURCES OF RIVERDALE, A COMPANY TOWN IN GOLIAD COUNTY, TEXAS

BY

John W. Clark, Jr.

Texas

State Department of Highways and Public Transportation

Highway Design Division

July 1984 


\begin{abstract}
Proposed realignment of a historic bridge at Riverdale, Goliad County, Texas, by the State Department of Highways and Public Transportation and new approach right-of-way on County Road 134 will affect portions of the community of Riverdale The community was founded by the Riverdale Gin and Milling Company and the Riverdale Mercantile Company in 1913, for the sole purpose of processing cotton. The community ceased to exist over the period from 1946 through 1952.
\end{abstract}




\section{TABLE OF CONTENTS}

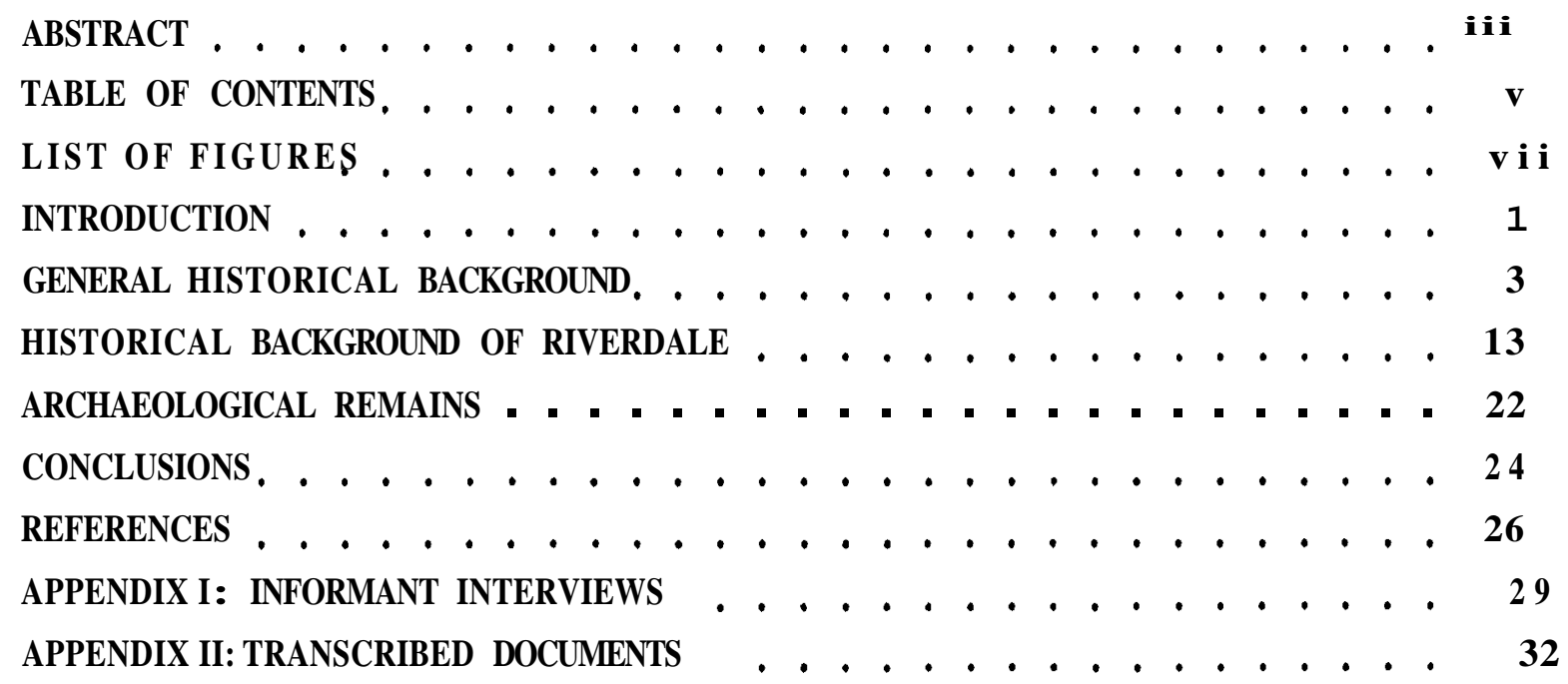




\section{LIST OF FIGURES}

FIGURE 1. Map of the Gulf of Mexico prepared by Alonso Alvarez de Pineda in 1519. . . . . . . . . . . . . . . 4

FGURE 2. The modern town of Riverdale. . . . . . . . . . 12

FIGURE 3. Property owned by the Mercantile Company and the Riverdale Gin and Milling Company in 1939 . . . . . 15

FIGURE 4. Observed archaeological remains of the Mercantile Company and the Riverdale Gin and Milling Company property in 1983. . . . . . . . . . . . . . 16

FIGURE 5. Plan view of structures associated with the Mercantile Company and the Gin and Milling Company . . . . . . 18

FIGURE 6. Contemporary photograph of the Riverdale School and unidentified students . . . . . . . . . . . 19

FIGURE 7. Contemporary photograph of the Riverdale Mercantile Company and unidentified gentleman. . . . . . . . 21 


\section{INTRODUCTION}

Interest in this site began with a proposal to replace the $100 \mathrm{ft}$. -long Warren pony truss bridge, crossing the San Antonio River at the town of Riverdale, as a segment of County Road 134. Since it is the policy of the Archaeology Section of the Highway Design Division, State Department of Highways and Public Transportation (SDHPT), to survey bridge relocations where there may be a possibility of archaeological sites, a survey was performed at the project location to locate any possible prehistoric remains, and to examine the previously recorded historic site of Riverdale (Site 41GD12) (Hester 1975:24).

The proposed project will involve the replacement of the bridge over the San Antonio River at a new location and the realignment of County Road 134, both to match with the new bridge location and to eliminate a right angle turn in the old road. The new right-of-way will be $100 \mathrm{ft}$. with two $10 \mathrm{ft}$. lanes. The old Warren pony truss bridge will not be retained due to objections of the landowner.

The survey and associated background research resulted in an assessment of the structural remains, the location of an early aerial photograph and contemporary maps of the property and structures, a small amount of informant information, and a small amount of historical data. This information was used to fill out a nomination form for the National Register of Historic Places so that a determination of eligibility could be made. In the opinions of archaeologists, from both the Archaeology Section of the SDHPT and the State Historic Preservation Office (SHPO) at the Texas Historical Commission (THC), the site meets the criteria for nomination.

In concord with the office of the SHPO, it was agreed that mitigation of the bridge replacement project would consist of the archaeological survey already performed on the site and more extensive archival research than had been done for the survey. Informant interviews 
conducted during the study are presented in Appendix I. Transcripts of deed records are presented in Appendix II. The bridge is to be treated separately and will be recorded through technical drawings and photographs.

Several persons were responsible for the collection of information herein reported. Dr. Clyde Bullion, of the Environmental and Community Factors Section of the Highway Design Division SDHPT, and Mr. Leo J. Gleinser, Senior Resident Engineer of the SDHPT residency in Goliad, provided some of the information on the early community. More complete archival research was performed by members of the Goliad County Historical Commission at the request of the SDHPT. The initial survey and archival search were performed by the author of this report. 
GENERAL HISTORICAL BACKGROUND

European occupation of the area now known as Goliad County stemmed from the explorations and mapping of the Gulf Coast by Alonso Alvarez de Pineda in 1519 (Fig. 1). The shipwrecked members of the Panfilo de Narvaez expedition to Florida of 1527 landed, mostlikely, on the barrier island at present Matagorda Bay. Four members of the expedition survived to tell the tale (Nunez Cabeza de Vaca 1906: 35-131) and to provide information on the prehistoric occupants of the vicinity of Goliad County. The first European settlement in the area was on present Garcitas Creek near its mouth at Matagorda Bay, then thought to be La Bahia del Espiritu Santo marked on the Pineda map.

There were rumors of a French colony established somewhere on the Spanish Gulf Coast. An extensive hunt was taken up both on land and sea by Spanish officials (Weddle 1973), having little effect until Alonso de Leon, Governor of Coahuila, entered the area in 1688 and captured the French survivor Jean (Juan) Gery (de Leon 1688a and 1688b). Following the .destruction of La Salles Fort St. Louis and the capture of the remainder of the French survivors, another expedition led by Alonso de Leon was sent to La Bahia del Espiritu Santo to establish a presidio and to establish missions among the Tejas Indians (de Leon 1690). A presidio was first placed at the site of Fort St. Louis in April of 1722 by the Marquez de San Miguel de Aguayo on his colonizing expedition (Santos 1981:78-79, 98-103). The presidio was named Nuestra Senora de Loreto. The Mission of Espiritu Santo de Zuniga was also founded.

The La Bahia del Espiritu Santo establishments were moved to Mission Creek (now in Victoria County) and the Guadalupe River in 1726 and finally to the San Antonio River in 1750 (O'Connor 1966:10-23). This final location served as the seed from which the present community and county of Goliad grew. Along the San Antonio River, a large number of missions and private ranches was established (Myres 1969, Weddle and 


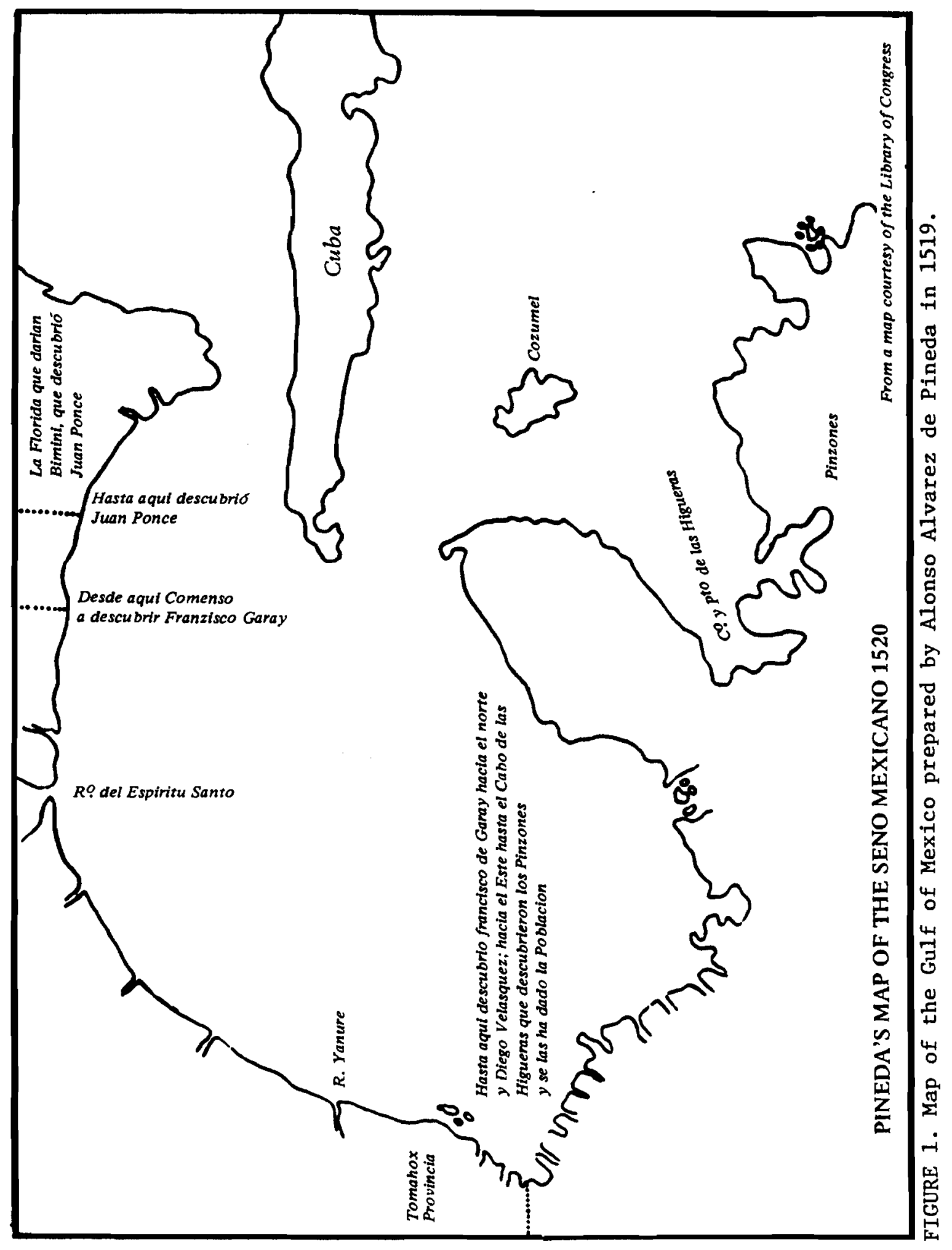


Thonhoff 1976). The community survived secularization attempts in the early 1790s and the missions continued, albeit at a reduced level of population and activity, until 1823.

With Napoleonic usurpation of the Bourbon monarchy in Spain, disaffected criollos, Indians, and mestizos of New Spain (Mexico) revolted in 1810 under the leadership of Fr. Miguel Hidalgo Costilla. Much of the revolution was crushed in 1811 with the capture and execution of Hidalgo; but one of his followers, Bernardo Gutierrez, then in Washington, allied himself with American Lieutenant Augustus W. Magee and made plans to invade Texas and establish a republican state to be annexed either to a republican Mexico or to the United States. Spanish Governor Manuel Salcedo established himself at La Bahia (later Goliad). Through a misestimation of the route of the army of Gutierrez-Magee and good intelligence work by the Gutierrez-Magee party, the community was virtually abandoned and was easily occupied. Salcedo made several attacks on the site but failed to dislodge the Republicans. Eventually he was forced to return to San Antonio where he was finally defeated and murdered (Almaraz 1971).

Other filibusters including Perry and Long entered the community until 1821 when the Treaty of Cordoba was signed, creating the republic of Mexico (Garrett 1969). In an attempt to populate the sparsely populated province of Tejas, an empresario grant system was instituted with the first colony established by Missourian, Stephen Fuller Austin. In the Goliad area were the San Patricio colony of Irish settlers and the nearby Powers colony. By 1829 a new settlement began two miles north of the presidio and was given the name Goliad, an anagram of the last name of Fr. Hidalgo.

In 1830, the Centralists overthrew the Federalist government and all colonization efforts were halted. Final secularization of the Missions Espiritu Santo de Zuniga and Nuestra Senora del Rosario took place at 
the same time. Farther east in the colonies of Austin and around Nacogdoches, the new colonists grew restive under the restrictive Centralist government. In 1832, the Federalists pulled off their own coup under the generalship of Antonio Lopez de Santa Anna. Texas declared in favor of the Federalist consititution of 1824, resulting in brief skirmishes at Velasco and Nacogdoches.

The period between 1833 and 1835 was complex in Mexican politics, finally resulting with Lopez de Santa Anna in power, this time as a Centralist. Meanwhile, Goliad suffered a serious cholera epidemic (Pruett and Cole 1983:8-10). As a result of the Centralist government, the territory of Quintana Roo, the state of Yucatan, the state of Veracruz, the state of Zacatecas, and the Texas portion of the state of Coahuila $y$ Texas rebelled.

In September of 1835, government forces attempted to disarm colonists at Gonzales, resulting in a small fracas. In October, a group led by George Collingsworth and Ben Milam took the presidio at La Bahia with few casualties on either side. By this time the fever for action was high. Dr. James Grant of Saltillo proposed an attack on Matamoros. This attack was, however, preceded by a small battle at Bejar. In order to proceed with the Matamoros venture, supplies were stripped of the Tejano garrison at Bejar. James Fannin was placed in command of a reserve or second wave group. When he heard of the approach of the Mexican army he attempted to advise Grant to withdraw but Grant would not listen. Fannin concentrated at Presidio de La Bahia (Loreto) now renamed Fort Defiance. In February of 1836 he received orders to reinforce the garrison at Bejar and, after an aborted attempt, gave up.

In March, the Mexican army sent a small contingent to San Patricio, capturing the commands of Grant and Johnson (Pruett and Cole 1983:12) after the fall of the "Texian" garrison at the fortified mission of San Antonio de Valero. Fannin was ordered to withdraw from La Bahia 
(Goliad) toward Victoria. A battle ensued with Mexican forces under general Jose Urrea at the mission Nuestra Senora del Rosario (Castaneda 1971). Following this battle, Fannin burned all supplies that couldn't be carried and started for Victoria in the face of Urrea's scouts. Later in the day, Urrea's column confronted Fannin. Rather than withdraw to a defensive position, he formed a square in an open field. The position was surrounded and fighting continued until dark. The next morning a request for surrender was dispatched to Fannin. The prisoners of war were returned to La Bahia (Brown 1970:601-609; Castaneda 1971:221-230). On orders from Santa Anna the majority of the prisoners were executed.

The events at Bejar and La Bahia precipitated a mass flight of Anglo colonists, known as "the runaway scrape." The war was precipitately ended in a field at the confluence of Buffalo Bayou and the San Jacinto River with the capture of the Mexican president, General Antonio Lopez de Santa Anna. General Vicinte Filisola, an Italian in the service of Mexico, was in charge of the Mexican garrison at La Bahia following the capture of his commanding general. In May of 1836 Filisola proceeded to remove the Mexican army south of the Rio Bravo (Rio Grande).

Following the removal of the Mexican army, Lipan and Comanche Indians made raids on the herds, and lagging Mexican soldiers also hit the ranches. Land speculation was rampant with many newcomers encroaching on old established grants. Meanwhile, General Urrea replaced Filisola and was ordered by the Mexican president pro tempore to proceed against Texas from headquarters in Matamoros, Tamaulipas. Three Mexican ships were captured in Copano; with them information was gained that Urrea was planning a new operation against Texas. Because of the discovery of the operation and recognition of independent Texas by England and France, the invasion was held off until March of 1842 (Pruett and Cole 1983:16). On that date Goliad was raided by a force of 40 men; and another group led by General Vasquez appeared at Bejar, occupied the 
town for a couple of days, and returned to Mexico with much of the Hispanic population.

A second Mexican invasion of the Republic took place in September of 1842, and was led by General Adrien Woll. The Battle of Salado Creek, i n Bexar County, took place after Woll occupied the town. Shortly thereafter, Woll retreated to Matamoros (Nance 1964:344-363). Following this retreat, the Texans planned the disastrous Mier expedition of December of 1842 (McCutchan 1978). Naturally, military units were frequently passing through a wild and dangerous Goliad. In December 1845, Texas was annexed to the United States and Anson Jones, president of the Republic of Texas, turned over the reins of government to Governor J. Pinckney Henderson in February of 1846.

United States troops were stationed in the area called the Nueces Strip which was claimed, with no historical foundation, by Texas. Their presence soon resulted in the battles of Palo Alto and Resaca de 1 a Palma and was the beginning of the war with Mexico in which Mexico lost about half its national territory to the United States. Texas Rangers took part in early fighting but were withdrawn, both because General Zachary Taylor considered them too unruly and to protect the Texas frontier from Indian attack (Pruett and Cole 1983:18-19). Several Ranger companies continued with Taylor, however. After the capture of Mexico City, the Treaty of Guadalupe Hidalgo was signed, ceding all of Texas, and the territory of New Mexico, Arizona, Colorado, Nevada, Utah, and California to the United States (Meyer and Sherman 1979:346-353).

Following the war, with security established, trade boomed, with wagon trains going from Indianola through Goliad to San Antonio and New Braunfels. European immigrants began to enter the area from Germany, Alsace, Bohemia, Poland, and other regions. As trade and immigration increased, the community prospered and developed. The economy was also aided by immigrants going to the California gold fields who were passing 
through and having wagons built in Goliad. During this period was an affair called the "cart war"--the result of competition between local freighters and carreteros hired by merchants in San Antonio. Ambushes, sabotage of carts, and vigilante hangings characterized the year 1851 (Pruett and Cole 1983:20).

During the period following the Mexican War and preceding the War Between the States, the Hillyer Female College, the Aranama College, Goliad College, and Paine Female Institute were founded. The development of the area as an eductional center was suspended when the Civil War began in 1861. The entire student body of Aranama college enlisted for the state militia and other men of the county either volunteered for various unite or were conscripted. The few slaves in the county continued working throughout the war. Being on one of the major cotton routes, Goliad had much traffic pass through until the coast was blockaded. The local economy then became one of subsistence (Pruett and Cole 1983:22-23).

With the end of the Civil War, and the attendant loss of property and military rule by the conquerors, many people were ruined economically. Negro troops were placed in charge of the town and county of Goliad. Imposed new laws caused considerable resentment on both sides; ex-slaves refused to work for wages. This situation produced "Black Codes" attempting to require blacks to work for their sustenance. General Charles Griffin of the occupation army removed from office the duly elected governor and established military rule. He was succeeded by GeneralJ.J. Reynolds, who forced the election of E.J. Davis as governor in a travesty of an election (Ramsdell 1970:108-114). Davis created a state police force directly under his orders, which was responsible for serious trouble and violations of the law across the state; and democratic party meetings were broken up. One group of police operating in the Goliad area became known as the "regulators." 
The election of 1873 defeated the carpetbag government. Davis attempted to have the United States Army intervene but it refused to do so and state government was returned to the democratic process. With the return of more settled conditions, the farmers and ranchers could concentrate on the economic development of the county. The cattle had proliferated during the war and proved to be a major economic foundation, as they were during the Spanish Colonial Period. Cotton raising was the second major economic pursuit, with gins in every town in the county. The 1870 s and ' 80 s were boom years in cotton culture; they were also the years of the great cattle drives. The Sedalia, Chisholm, and Western Trails passed near Goliad. The Western Trail was much used by Goliad ranchers (see map in Dary 1981:172). Cattle drives came to an end in 1889 when the New York, Texas, and Mexican Railroad Division constructed a railroad in the county (Pruett and Cole 1983:30).

In August of 1889, a hurricane destroyed Indianola, the port for Goliad, and caused damage in Goliad itself. A tornado hit the town in 1902, destroying a part of the town including the San Antonio River Bridge and Brooks College (Pruett and Cole 1983:39-41). Some 114 people were killed and 225 injured.

When World War I was underway the United States sent as a part of its contribution the 36th Infantry Division, including a Goliad Company (K) which saw action in France and Belgium. Following the war, agriculture continued to develop. Archaeological investigation and restoration was done by the Work Projects Administration and the Civilian Conservation Corps in the 1930s on Espiritu Santo de Zuniga and Presidio Nuestra Senor de Loreto de $1 \mathrm{a}$ Bahia; and preliminary excavation was done at Nuestra Senora del Rosario, the Fannin battlefield, and other public properties in the county. Other events in the years between the world wars included a tick quarantine in 1921, the purchase of a water works system in 1926, inauguration of the use of natural gas in 1928, first paving of streets in 1930, purchase of land for a state park in 1930, 
construction of a sewer system in 1930, and construction of sidewalks in 1933 (Pruett and Cole 1983:215-216).

Goliad men and women served in World Warll in a variety of geographic areas and in many capacities. Following the war the veterans returned to take up ranching, farming, and commerce. Restoration work on the presidio was completed in 1967 and Texas Parks and Wildlife Department staff completed work on restoration at Espiritu Santo in 1977. A county historical commission was created in 1955. This organization was responsible for placing historical markers on sites in the county, the erection of a monument at the birthplace of General Ignacio Zaragosa, the publication of a county history (Pruett and Cole 1983), and the establishment and maintenance of a county museum. In September of 1979 the last train ran through Goliad. The tracks were subsequently torn up.

Throughout the period of historic occupation of the area of Goliad County, cattle ranching and, later, farming have been the twin economic bases of the county. Cattle ranching began in the mid-eighteenth century when Espiritu Santo de Zuniga and Nuestra Senora del Rosario were moved to the San Antonio River, while the cultivation of cotton began following the Texas Revolution. The cattle industry saw two major boom periods--the late eighteenth century and the late nineteenth century. Cotton raising also saw two major periods of expansion--late nineteenth century and the period following World Warl. The second boom period saw the founding and growth of a unique community wholly oriented toward cotton processing - Riverdale (Fig. 2). 
This Page Redacted Per THC Policy 


\section{HISTORICALBACKGROUND OF RIVERDALE}

Among the colonists in Stephen F. Austin's colony was William Albert (Buck) Pettus, his wife Elizabeth, and son John Freeman Pettus who, in 1822, settled on Palmetto Creek near San Felipe (Ray 1970:13) in what later became Austin County. His brother Freeman Pettus located near Columbus in what was to become Colorado County. They immigrated from Alabama and were previously from Virginia (Ray 1970:182). John F. Pettus served with Ben Milam at the battle of Bexar, fought at Concepcion under Moseley Baker, and was at the battle of San Jacinto. He served in a temporary Ranger company for 18 months (Pruett and Cole 1983:308).

John F. Pettus was married to Sarah York in 1836. For his service to the revolution he received one bounty grant of land and one donation grant (320 and 640 acres respectively) in 1838 (Miller 1967:526,828).

The bounty warrant was located in Goliad County and was surveyed but not patented. The warrant was rejected by the commissioner of the Court of Claims in 1857. The donation grant was patented to him in Llano County in 1846. He at that time also received a bounty warrant for 640 acres in Llano County patented at the same time as the donation grant. Pettus apparently sold or traded his Llano County land for land in Victoria County and in 1859 purchased approximately 1000 acres.

Pettus and his oldest son served in the Confederate Army, but neither applied for pensions. Sarah York Pettus helped establish the first church in Charco, and the community of Dry Medio was renamed Pettus after John F. (Pruett and Cole 1983:308). The Pettus family prospered and the land was divided among the heirs who attained their own status i n the Goliad community.

In 1913, a corporation of investors was formed, calling itself the Riverdale Gin and Milling Company. Apparently, one of the investors or associates was J.M. Pettus who sold 3.5 acres of land on the Berclair- 
Charco road, at a sharp bend in the San Antonio River, to the Gin and Milling Company (Goliad County Deed Records, Vol. 38:509). There may already have been an incipient settlement in the area at this time. In any event, by 1915 there was also created the Riverdale Mercantile company. Pettus sold additional land to the combined companies. Over a period of time, the Mercantile Company acquired 10.57 acres, while the Riverdale Gin and Milling Company purchased 13.77 acres (Figs. 3 and 4). One of the sales (J. M. Pettus and Sallie Pettus) to the Riverdale Mercantile Company of five acres was made for $\$ 10$, clearly indicating personal interest in the enterprise (Goliad County Deed Records, Vol. $70: 420-422)$.

James N. Lincoln was the only president of the company (in 1939) whose name was found in courthouse records. W. L. Lutenbacher was the secretary for the Gin and Milling Company, and V. W. Clarke (Doris Bluntzer and Agnes Lutenbacher, personal communication) operated the gin and later the Mercantile store.

By 1916, a school was started with Sophie Seidel Williams as the first teacher (Sophie Seidel Williams, personal communication). The other teachers were Mrs. Helen Lott in 1926 (Goliad County Public Bulletin 1925-1926) who continued until 1949, and Mrs. Gussie Pettus in 1916. A Mr. Koenig ran a blacksmith shop at the site, aided by a Mr. Harding. Mitchel Seeligson, was the first manager of the Mercantile Company (John Freeman Lott, Sr., personal communication).

Over a period of time, several structures and businesses developed, associated with both the Gin and Milling Company and the Mercantile Company. Structures eventually associated with the Gin and Milling Company were the gin, cotton derrick, seed house, cotton house, scale house, engine room--including the light plant and grist mill, laborers' quarters, gasoline storage shed, sleeping porch, hotel, lasarine house or infirmary, the gin foreman's residence and outhouse, the bookkeeper's 


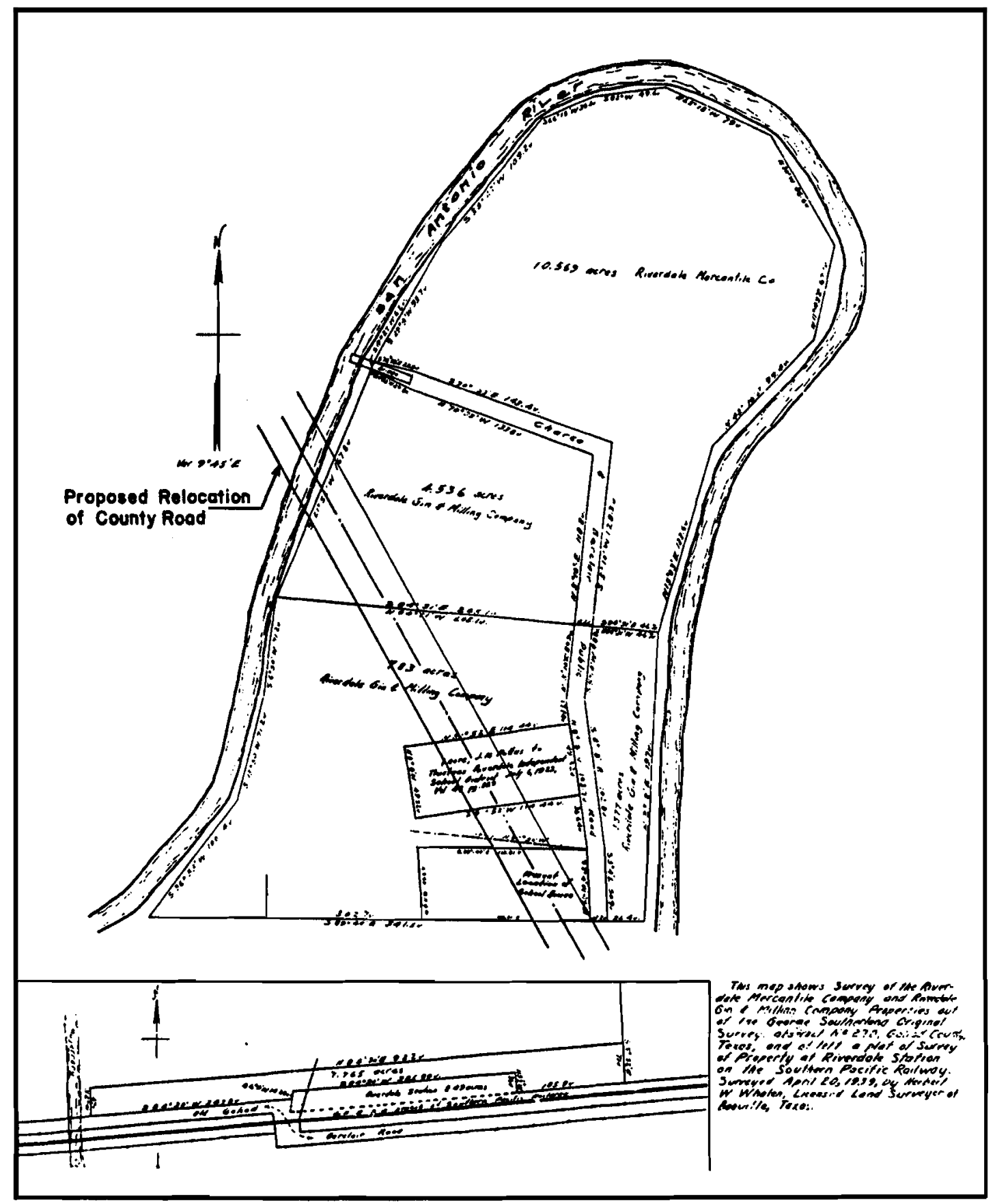

FIG URE 3. Property owned by the Mercantile Company and the Riverdale Gin and Milling Company in 1939. 


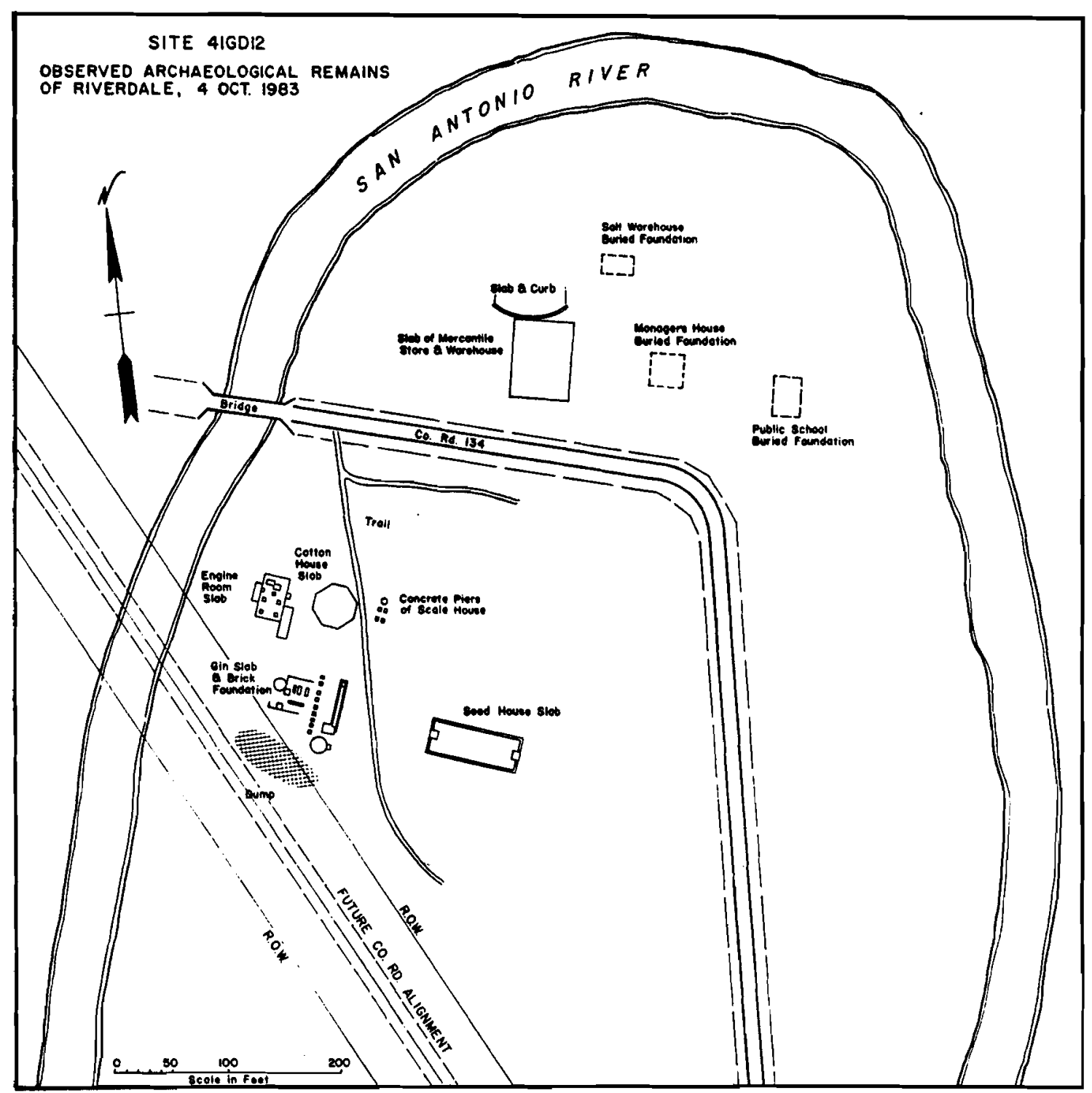

FIGURE 4. Observed archaeological remains of the Mercantile Company and the Riverdale Gin and Miling Company property in 1983. 
house and outhouse, and a school. Buildings associated with the Mercantile Company were a barber shop, drayman's building, the Mercantile store and warehouse, salt warehouse, manager's house, stable, a second school locality--perhaps the teacher's house, market, and blacksmith's shop (Fig. 5).

The Riverdale school was to be constructed on a lot purchased from J. M. Pettus in 1923 (Goliad County Deed Records, Vol. 48:329). Through an error, the school was built in another, nearby, area. This tract was purchased by the Riverdale Independent School District, from the Riverdale Gin and Milling Company, in 1939 (Goliad County Deed Records, Vol. 90:16). By 1953, the school (Fig. 6) was no longer being used by the Goliad County Independent School District (successor to Riverdale Independent School District) and was relinquished to J.M. Pettus (Goliad County Independent School District Board of Trustees Records, Vol. $156: 415)$.

Associated with the Riverdale Gin and Milling Company and the Riverdale Mercantile Company was the Riverdale Station on the Southern Pacific Railroad near Berclair. This property was purchased from W. F. Pettus i n 1915 (Goliad County Deed Records, Vol. 40:1) to serve as the railroad terminus for the companies.

Associated with the community of Riverdale was County Road 134 and the bridge crossing the San Antonio River at this point. Archival research has failed to reveal when the Warren pony truss bridge was built. Apparently it was in place fairly early in the existence of the community if not predating it. The deed for five acres of land sold to the Riverdale Mercantile Company by J.M. and Sallie Pettus (Goliad County Deed Records, Vol. 70:420-422) described the property thusly: "...beginning at the south or southwestern part of the public bridge across the said San Antonio River, on the public road leading from Berclair to Charco..." . Although the deed is dated 1933, it would 


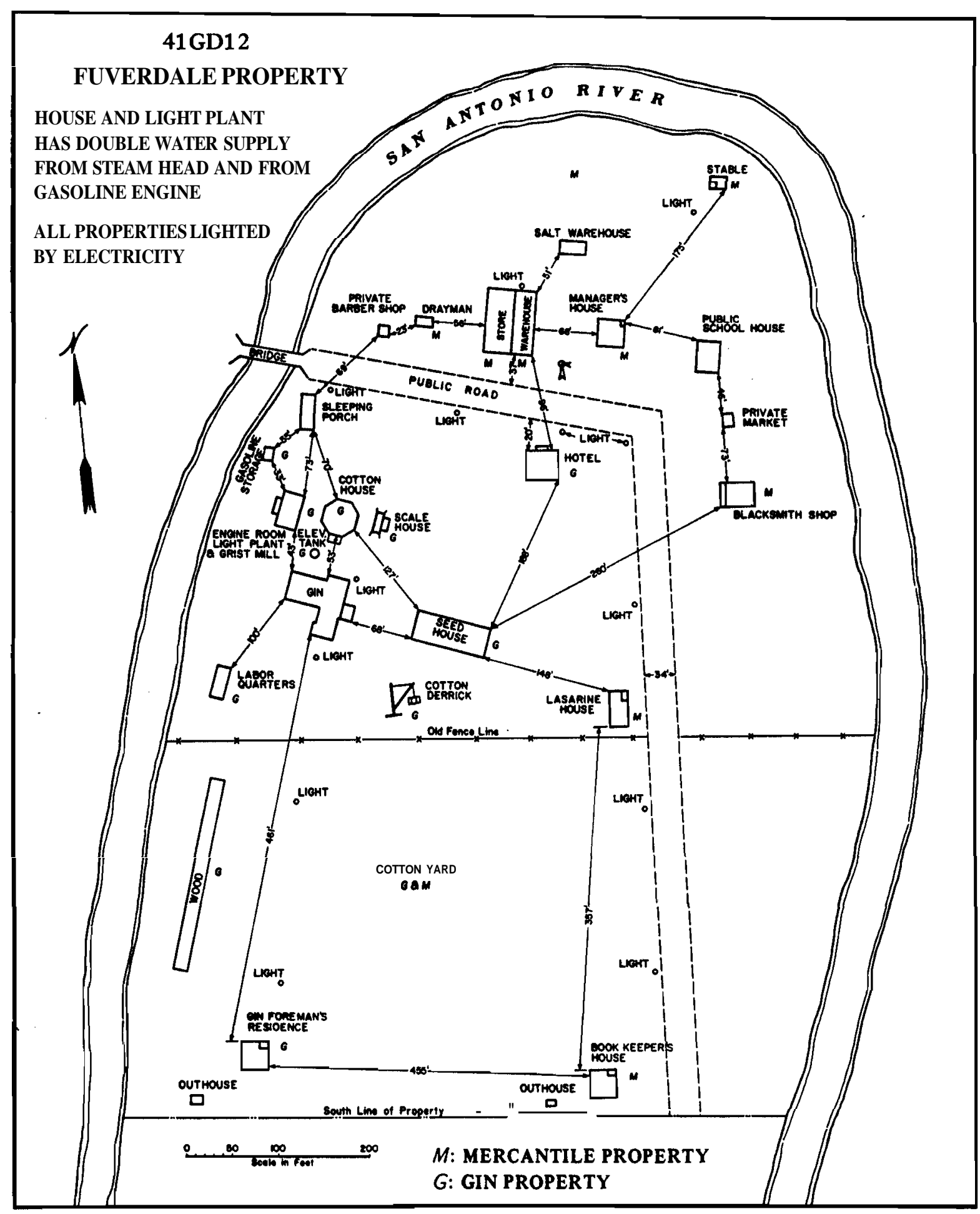

FIGURE 5. Plan view of structures associated with the Mercantile Company and the Gin and Milling Company. 


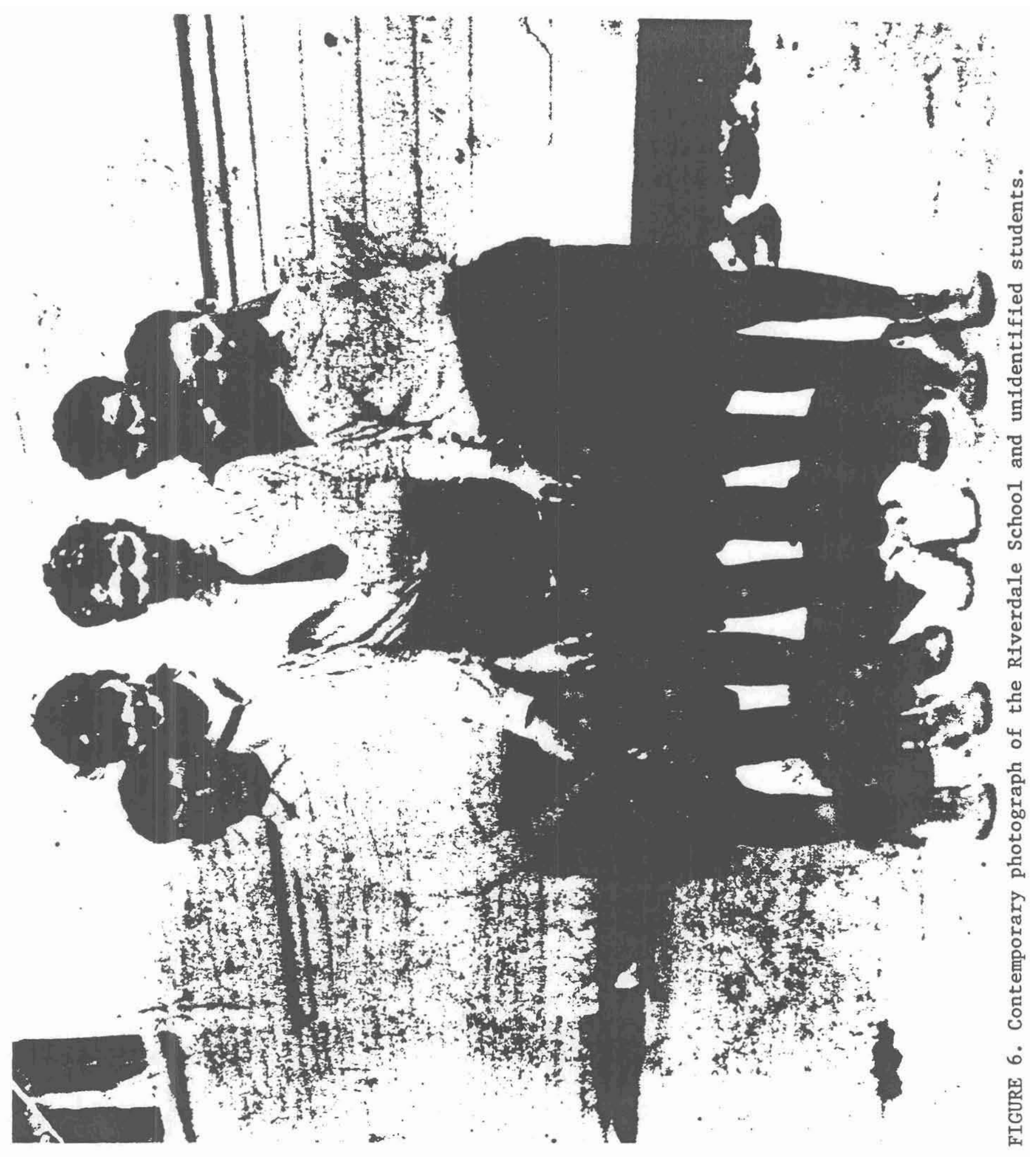


suggest that the bridge had been a part of the meets and bounds originally.

Although the bridge has never washed out in a flood, it has undergone repairs at various times. The most notable case occurred in the early 1930s (John Freeman Lott, Sr., personal communication) when a wagon crossing the bridge started the bridge swaying. The deck apparently collapsed behind the wagon. The wagon, team, and driver reached the other side and much of the bridge had to be rebuilt.

Sometime between 1941 and 1953 most of Riverdale was abandoned and the structures collapsed or were torn down. The Mercantile Company store (Fig. 7) and school were apparently the last buildings to be removed. The school was still in operation in 1949 (the city directory for 1948-1949 lists Mrs. Helen C. Lott as teacher and principal with 46 students). Mr. John Freeman Lott, Sr., indicates that the Mercantile store was the last structure standing in the community and was torn down in the early 1950s. The bricks were reused in a nearby residence. 


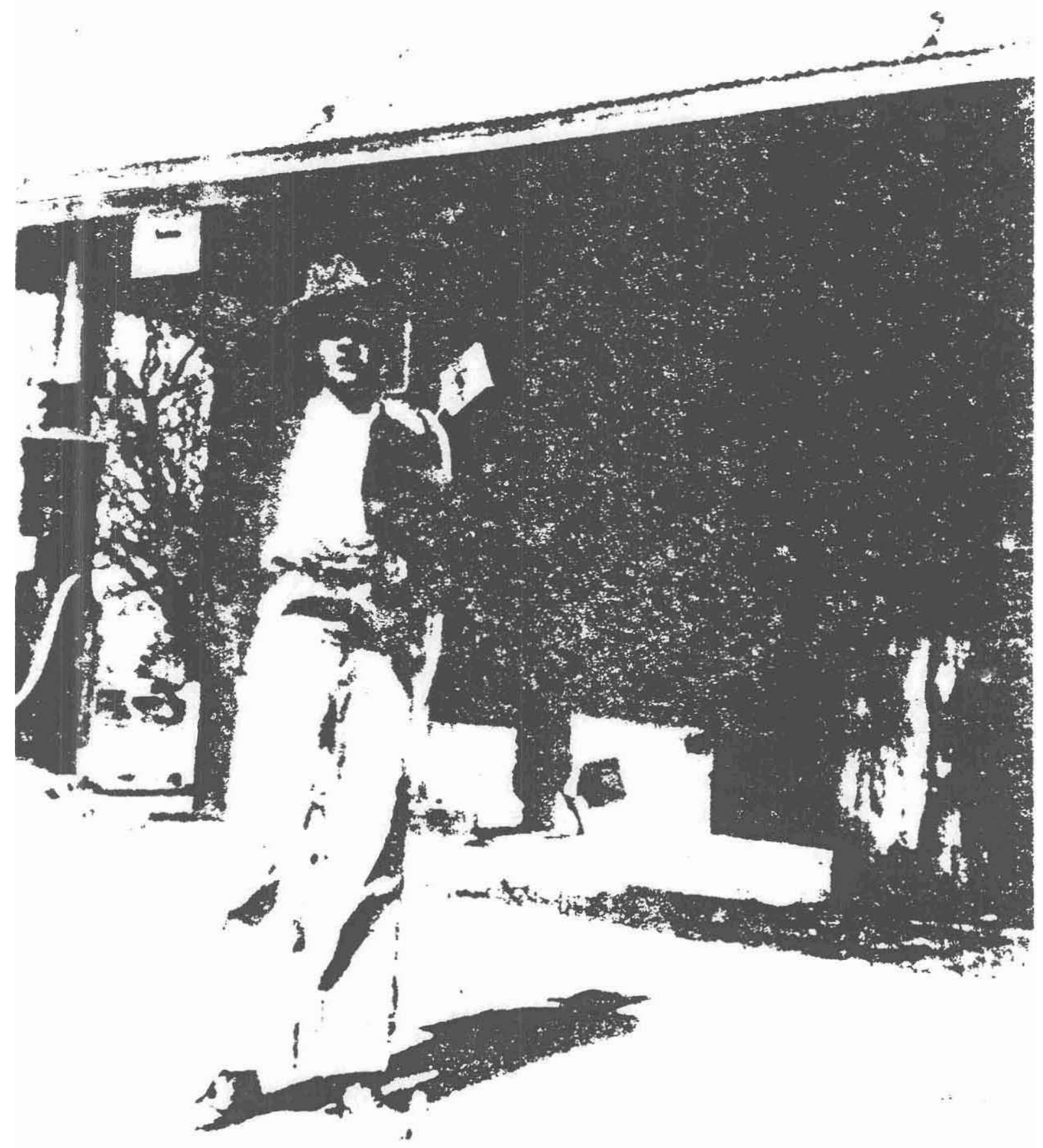

FIGURE 7. Contemporary photograph of the Riverdale Mercantile Company and unidentified gentleman. 


\section{ARCHAEOLOGICAL REMAINS}

An archaeological reconnaissance of the proposed bridge replacement at Riverdale was performed in October of 1983. At that time a number of foundation remains including slabs in some areas, foundation walls, and piers in other areas were recorded (Fig. 5). The observed remains can easily be associated with known site structures as shown on a contemporary map of the property. The most substantial foundation is a combination concrete slab and brick pier complex associated with the gin. The features of the foundation include a concrete-walled trough, a line of brick piers, and circular structures.

The remains of the seed house consist of a flat slab with low raised walls. Ramps are present on both ends of the foundation. The cotton house foundation is a $36 \mathrm{ft}$. by $36 \mathrm{ft}$. octagonal slab. East of the cotton house are the foundation remains of the scale house, consisting of four heavy concrete piers and a circular slab on the north side. West of the cotton house is the raised slab of the engine room with its engine mounts and depressed areas. On one of the engine mounts is inscribed "Erected March 13th 192_."

North of County Road 134 are the remains of buildings of the Riverdale Mercantile Company. The most substantial of these remains is the raised slab of the Mercantile store and warehouse. Associated with this structure is a circular bed on the north end of the west wall and a large, low-curbed circular slab. The presence of other structures including the salt warehouse, manager's house, and school building is indicated by shallow depressed areas with no undergrowth.

Three brick types were observed. The vast majority of bricks were unmarked. One variety was stamped "D'Hanis" and was imported from D'Hanis, Texas, southwest of San Antonio. Other bricks were stamped by a St. Louis manufacturer. Other materials observed at the site include fragments of window pane, glass electrical insulators, sheet iron, and 
machine parts. An area south of the gin appears to have been a small dump. Materials observed there include tin can fragments, fragments of bottle glass, and sheet iron. 
CONCLUSIONS

Clearly there are very substantial remains of the site readily visible. Archival material and informant interviews add a great deal of knowledge concerning the site. It is also clear that there are great gaps in the archival record. It is certain that some of the gaps could be filled by further research in county tax, deed, trust, and other records. It is likely that some additional information could be gleaned from further interviews conducted with specific goals in mind and recorded on tape. The potential for further research is very great. This research would have to include a great deal of archaeology in order to answer several very important questions, among them questions regarding the magnitude of business and types of goods available at the Mercantile store and where they came from, the relationship between the various businesses, residences, services, and industrial functions, artifactual differentiation between industrial, service, and residential structures, and other questions.

Because the proposed bridge relocation and approach will affect a small portion of the site, impacting a portion of the laborers' quarters, the outhouse of the bookkeeper, and a shallow dump area, it is believed that further work in these areas would provide little additional information. Since SDHPT work on the site would necessarily be limited to the new right-of-way, the major structures of the site could not be investigated by the SDHPT.

The town site of Riverdale is unique in the county; it is the only company town. All other contemporary communities in the area were essentially residence and commerical centers with relatively diversified economic bases--cotton, cattle, and a variety of small businesses. The existence of the community depended directly on the success of the combined Gin and Milling Company and the Mercantile Company. The town was established with a railhead purchased separately in 1913. It grew 
and prospered for years and then rapidly declined in the years immediately following World War II. The entire focus of the community was oriented to the processing of cotton and those things needed to support that industry. 


\title{
REFERENCES
}

References Cited

\begin{abstract}
Almaraz, Felix D. Jr.,
I971 Tragic Cavalier: Governor Manuel Salcedo of Texas, 1808-1813. The University of Texas Press. Austin.
\end{abstract}

Brown, John Henry

1970 History of Texas from 1865 to 1892. 2 vols. Facsimile of the 1892 edition. Jenkins Publishing Company. Austin.

Castaneda, Carlos E. (Translator)

1971 The Mexican Side of the Texan Revolution (1836) by the Chief Mexican Participants. Documentary Publications. Washington, D.C.

Dary, David

1981

Cowboy Culture: A Saga of Five Centuries. Avon Books. New Y ork.

de Leon, Alonso

1988a Carta de Alonso de Leon a I Virrey (Monterrey, 21 de Junio de 1688). Reprinted in Gomez Canedo, 1968, Primeras Exploraciones y Poblamiento de Texas (1686-1694). Publicaciones del Instituto Tecnologico y de Estudios Superiores de Monterrey, Serie: Historia 6. Monterrey.

1988b Derrotero y demarcacion de la tierra de la jornada que por orden del Excelentisimo Senor Conde de Monclova. Reprinted in Gomez Canedo, 1968, Primeras Exploraciones $y$ Poblamiento de Texas (1686-1694). Publicaciones del Instituto Tecnologico y de Estudios Superiores de Monterrey, Serie: Bistoria 6. Monterrey.

1690 Diario del general Alonso de Leon en su entrada a Texas desde Coahuila. Reprinted in Gomez Canedo, 1968, Primeras Exploraciones y Poblamiento de Texas (1686-1694). Publicaciones del Instituto Tecnologico y de Estudios Superiores de Monterrey, Serie: Historia 6. Monterrey.

Garrett, Julia Kathryn

1969 Green Flag over Texas: A Story of the Last Years of Spain in Texas. Jenkins Publishing Company. Austin.

Goliad County Independent School District

Board of Trustees Records. 


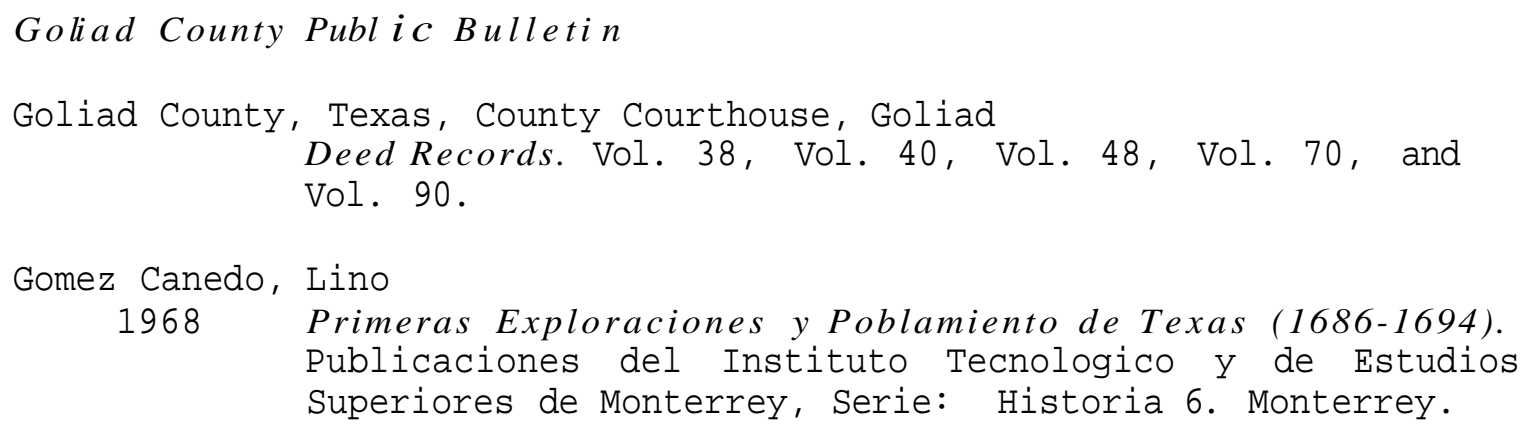

Meyer, Michael C., and William L. Sherman

1979 The Course of Mexican History. Oxford University Press. New York.

Miller, Thomas Lloyd

1967 Bounty and Donation Land Grants of Texas 1835-1888. University of Texas Press. Austin.

Myres, Sandra L.

1969 The Ranch in Spanish Texas 1691-1800. Social Science Series 2. Texas Western Press. El Paso.

Nance, Joseph Milton

1964 Attack and Counterattack: The Texas-Mexican Frontier, 1842. University of Texas Press. Austin.

Nunez Cabeza de Vaca, Alvar

1906 Relacion de los Naufragios y Comentarios de Alvar Nunez Cabeza de Vaca, Adelantado y Gobernador del Rio de la Plata. Coleccion de Libros y Documentos Referentes a la Historia de America, Tomov. 2 vols. Libreria General de Victoriano Suarez, Madrid.

O'Connor, Kathryn Stoner

1966 The Presidio La Bahia del Espiritu Santo de Zuniga 1721 to 1846. Von Boeckmann-Jones Company. Austin. 
Pruett, Jakie L., and Everett B. Cole

1983 The History and Heritage of Goliad County. Eakin Publications, Inc. Austin.

Ramsdell, Charles William

1970 Reconstruction in Texas. Texas History Paperbacks, University of Texas Press. Austin.

Ray, Worth S.

1970 Austin Colony Pioneers. Jenkins Publishing Company. Austin.

Santos, Richard G. (Translator)

1981 Aguayo Expedition into Texas 1721: An Annotated

Translation of the Diary Kept by Br. Juan Antonio de la

Pena. Jenkins Publishing Company. Austin.

Weddle, Robert S.

1973 Wilderness Manhunt: The Spanish Search for La Salle. University of Texas Press. Austin.

Weddle, Robert S., and Robert H. Thonhoff

1976 Drama and Conflict: The Texas Saga of 1776. Madrona

Press. Austin.

\section{Informants Cited}

Bluntzer, Doris

Lott, John Freeman, Sr.

Lutenbacher, Agnes

Williams, Sophie Siedel

Additional information on the informant interviews is presented in Appendix I. Interview records are on file in the SDHPT Archaeology Lab, Austin, Texas. 
APPENDIX I: INFORMANT INTERVIEWS

During the 1983 and 1984 investigations for this report, a number of former Riverdale residents were interviewed by the Goliad County Historical Commission. Their summaries are herein provided.

\section{Doris Bluntzer}

Doris Bluntzer moved to Riverdale about 1916. Her father, V. W. Clarke, ran the gin. He also had a mill where he ground corn meal for residents who came to town on Saturdays. She said her father ginned day and night for several months of the year. There were five or six Anglo families living in town at that time, plus several families of Mexicans and some Negroes who lived in little houses furnished by the company. The town of Riverdale was built along the inside curve of the river. There was one large general store, the Riverdale Mercantile. Mrs. Bluntzer worked in the dry goods department there after she graduated from high school. The store had a soda fountain on one side. She says that the school only went to the tenth grade, so she had to go into Goliad to finish school. There is a slab east of the bridge where the old store stood. There was also a blacksmith shop run by Mr. Koenig, the father of Agnes Lutenbacher.

\section{John Freeman Lott, Sr.}

A group of farmers and landowners in the area established the community of Riverdale in the early 1900s. There was a cotton gin, a blacksmith shop, a hotel, a general store, a school, and several related buildings. There were seven or eight houses built that were homes for the people who ran the community businesses. Mitchell Seeligson was the original manager of the Riverdale Mercantile, and Bill Lutenbacher succeeded him and ran it until it closed in the late 1930s. 
"Mr.P.N. Clarke ran the Riverdale cotton gin forever; and though I can't recall the name of the first blacksmith, one of the blacksmiths was Mr. Harding and another was a Mr. Koenig. Mae Baker could tell about that 'cause Larry Baker worked there as a young man," relates Mr. Lott.

In the early '30s a man that was working for Ramsey's crossed the Riverdale Bridge with a wagon and team. The horses were trotting and the bridge got to swaying and fell in--collapsed--right behind the wagon. The man, team, and wagon reached the other side but the bridge had to be rebuilt.

The Riverdale Mercantile was a brick structure that was the last remaining building in the community. It was torn down in the late 1940 s or early 1950s, and the brick was purchased by the Alton Griffins to build a home across the San Antonio River just south of Goliad. The home is presently owned by the Buddy Wheelises.

\section{Agnes Lutenbacher}

Agnes Lutenbacher relates that people brought work to her father's blacksmith shop from many miles around, and often the men's wives would come also and spend the day at the Lutenbacher's home while the men were having their blacksmithing done. She says that her bother and a friend built a croquet ground next to the Koenig home and even equipped it with electric lights. Groups came from as far away as Berclair to play. Riverdale also had a very competitive baseball team for many years. Ms. Lutenbacher tells that there was also a meat market in Riverdale, owned and operated by Jim Lott, Jr. Be operated it only on weekends, since that was when all the country people came to town to shop. During the cotton season, a hotel was in operation. A black man did the cleaning, and his young wife had a cafe in the hotel. Ms. Lutenbacher says that sometimes they were "muddied in" during the winter, and just played 
dominoes and popped corn. There was ice delivery to Riverdale three days a week. The produce man came on Thursdays, leaving summer sausage at the store which was a treat. At one time the river came up and swallowed Agnes's brother's boat. When the river subsided, he found his boat still tied, but overturned, with a 60 lb. catfish trapped inside the boat.

\section{Sophie Seidel Williams}

Sophie Seidel Williams was the first schoolteacher at Riverdale (1916). The school was held in a one-room schoolhouse. She was 16 years of age when she went there to teach. She boarded with the Ramsey family who lived about a mile from the school. She took a pony with her to ride to school, but the pony got loose the first night she was there and went home to Goliad. "Miss Sophie" had to walk to school, and she remembers that she got soaking wet the first day. Another incident she remembers was that she fainted one day in the classroom and all her pupils ran outside--no one tried to help her or report her trouble to anyone. Some of the Mexican children who ran away never came back. Doris Clarke Bluntzer was one of "Miss Sophie's" students at that time, and Mrs. Bluntzer also told about the fainting incident. "Miss Sophie" taught for two years, then she took a business course and started working at the Goliad Bank. 


\section{APPENDIXII: TRANSCRIBED DOOUMENIS}

Included here are transcripts of selected documents pertaining to Riverdale and Riverdale Station. These documents are copies from Goliad County Deed Records and from minutes of the Goliad County Independent School District meetings. It is believed that these documents provide valuable data in the understanding of Riverdale.

Sale by W. F. Pettus of Land for a Railroad Terminal to the Riverdale Gin and Milling Company and the Riverdale Mercantile Company (Goliad County Deed Records, Vol. 40:1)

The State of Texas,

County of Goliad.

KNOW ALL MENBY THESE PRESENTS: That I, W. F. Pettus, of said county and state, for and in consideration of the sum of Five Hundred (\$500.00) dollars, cash to me in hand paid by the Riverdale Mercantile Company, and the Riverdale Gin and Milling Company, each private corporations, whose principal places of business are located in said Goliad County, Texas, the receipt of which is hereby acknowledged, have granted, sold and conveyed, and by these presents do grant, sell and convey unto the said Riverdale Mercantile Company and said Riverdale Gin and Milling Company, jointly, share and share alike, all that certain tract or parcel of land, situated in said Goliad County, Texas, it being seven and 51/100 acres, and being all of a certain ten acre tract, out of original grants in the names of A. McKinney, E. Hay, assignee, and G. Cortinas, conveyed to the granter herein by T. F. Pettus, by deed dated November $7 \mathrm{th}$, 1914, and recorded in Vol. 39, page 5621563, deed records of said Goliad County, Texas, which said deed of conveyance and the record thereof is made part hereof for further description of said ten acres, less, however but of said ten acres, two and 40/100 acres which is not conveyed hereby, said two 2-49/100 acres not included in this conveyance being described as follows: 
Beginning at a point 50 feet north of and at right angles from the center line of the main track of the G.H.\&S.A. Railway opposite Engineer's station No. 6767+11. Thence northward at right angles to said main track 100 feet for corner. Thence westward paralleled with and 150 feet from the aforesaid center line of said railway 1072.2 feet to fence for corner. Thence southerly following said fence 102.1 feet to a point for corner on north property line of said railway. Thence eastward along the said north property line 50 feet from and paralleled with the aforesaid center line of said main track 1092.8 feet to the place of beginning, containing 2-40/100 acres of land.

To have and to hold the above described premises, together with all and singular the rights and appurtenances thereto in anywise belonging unto the said Riverdale Mercantile Company, and the said Riverdale Gin and Milling Company, their successors and assigns, respectively, jointly, share and share alike, forever, and I do hereby bind myself, my heirs, executors and administrators to warrant and forever defend all and singular the said premises, and improvements unto the said Riverdale Mercantile Company and the said Riverdale Gin and Milling Company, respectively, their successors and assigns, gainst (sic) ever, person whosoever claiming or to claim the same or any part thereof.

Witness my hand at Goliad, Texas, this February 21, 1915.

T. F. Pettus

The State of Texas,

County of Goliad.

Before me, the undersigned authority, in and for said Goliad County, Texas, on this day personally appeared W. F. Pettus, known to me to be the person whose name is subscribed to the foregoing instrument, and acknowledged to me that he executed the same for the purposes and consideration therein expressed. 
Given under my hand and seal of office this February 26, 1915.

J. M. Pittman, Notary Public,

(SEAL) in and for Goliad County, Texas.

Filed for record A pril 9, 1915 at 11 o'clock a.m.

And duly recorded A pril 10, 1915 at 2 o'clock p.m.

(illegible) Clerk. 
Sale of a Tract of Land byJ.M. and Sallie Pettus to the

Riverdale Mercantile Company

(Goliad County Deed Records, Vol. 70:420-422)

J.M. PETTUS ET UX TO RIVERDALE MERCANTILE COMPANY

-QUITCLAIM DEHD-

THE STATE OF TEXAS,

COUNTY OF GOLIAD.

KNOW ALL MEN BY THESE PRESENTS: That we, J. M. Pettus and wife, Sallie Pettus, of Goliad County, Texas, for and in consideration of the sum of Ten (10.00) Dollars to us in hand paid by Riverdale Mercantile Company, a private corporation, of Goliad County, Texas, the receipt of which is hereby acknowledged, do by these presents bargain, sell, release and forever quitclaim unto the Riverdale Mercantile Company, its successors and assigns, all our right, title and interest in and to all that certain tract or parcel of land, situated in said Goliad County, Texas, being part of an original grant in the name of Geo. Sutherland, Abstract No. 270, situated the South side of the San Antonio river, about 12 miles West of the town of Goliad, containing Five (5) acres, more or less, having these metes and bounds:

BEGINNING at the South or Southwestern pier of the public bridge across the said San Antonio river, on the public road leading from Berclair to Charco;

THENCE in a northerly, easterly and southerly direction with the meanders of said San Antonio river, 690 yards, a large double tree, marked IVX on the Western bank of said river;

THENCE in a northeasterly direction, with the eastern boundary of said road, 107 yards, a stake, a bend in said road;

THENCE in a westerly direction 148 yards the north or northeastern pier of said bridge, directly opposite the place of beginning. 
This quitclaim deed is given for the reason that in the conveyance from J. M. Pettus to the Riverdale Mercantile Company, dated April 16th, 1913, of record in Vol. 38, page 508 of the deed records of Goliad County, Texas, the following provisions occurs, towit:

Provided, however, it is further understood by all parties hereto, that this conveyance is made to the grantee herein for the sole purpose of conducting a mercantile business thereon, and that in the event said grantee or its successors or assigns, shall use the same for any other purpose, or shall undertake to dispose of the same, or any part thereof, and the same is used for any other purpose, then the title and possession of said property shall forth revert to the Grantor herein.

And the main purpose of this instrument is to, and we do hereby remove said proviso, restriction or limitation contained in said conveyance, and we do hereby change and convert said conveyance into a general warranty deed without limitation or restriction of any kind or character whatsoever.

To have and to hold the said premises, together with all and singular, the rights, privileges and appurtenances thereto in any manner belonging unto the said Riverdale Mercantile Company, its successors and assigns, forever, so that neither we the said J. M. Pettus and wife, Sallie Pettus, nor our heirs, nor any person or persons claiming under us, shall, at any time hereafter, have, claim or demand any right or title to the aforesaid premises or appurtenances or any part thereof.

Witness our hand this the 11th day of February, A.D. 1933.

\section{J. M. Pettus}

Sallie Pettus 


\section{THE STATE OF TEXAS,}

COUNTY OF GOLIAD

Before me, the undersigned authority, in and for said state and county, on this day personally appeared J. M. Pettus and wife, Sallie Pettus, both known to me to be the persons whose names are subscribed to the foregoing instrument, and each acknowledged to me that they each executed the same for the purposes and considertation therein expressed, and the said Sallie Pettus, wife of the said J. M. Pettus, having been examined by me privily and apart from her husband, and having the same fully explained to her by me, she, the said Sallie Pettus acknowledged such instrument to be her act and deed, and declared that she had willingly signed the same for the purposes and consideration therein expressed, and that she did not wish to retract it.

Given under my hand and seal of office this 11 day of February, A.D. 1933 .

(SEAL)

W. E. Fouler, A Notary Public in and for Goliad County, Texas.

Filed for record March 2, 1933, at 2 o'clock P.M. And duly recorded March 2, 1933, at 4:20 o'clock P.M.

B. H. Bergmann Clerk, County Court, Goliad County, Texas. 


\author{
Resolution of the Riverdale Gin and Milling Company \\ Mortgaging Property for a Loan \\ (Goliad County Deed of Trust Records, Vol. X:28-46)
}

THE RIVERDALE GIN AND MILLING COMPANY TO

R. L. PETTUS W. L. LUTENBACHER

CERTIFIED COPY OF RESOLUTION

At a meeting of the Board of Directors of The Riverdale Gin and Milling Company, held at the regular meeting place on the 3rd day of July, 1939, a full quorum being present and a 11 participating, it was duly moved, seconded and carried that James H. Lincoln, as President of and for and inbehalf of this corporation shall forthwith make, execute and deliver a certain promissory note, said note to be also signed by certain shareholders of this corporation, calling for the sum of Fifteen Thousand $(\$ 15,000.00)$ Dollars, due on demand, payable to the order of The Riverdale Gin and Milling Company, at the office of The First National Bank of Goliad, in the City of Goliad, in Goliad County, Texas, bearing interest from date until paid at the rate of eight per cent per annum, the interest due and payable annually and providing if interest is not paid when due and the same shall become as the principal and bear interest at the same rate, due, payable and compounded annually. Said note shall also contain the usual ten per cent attorneys fee clause and payment thereof shall be secured to be paid by a deed of trust on certain real estate in Goliad County, Texas, consisting of the one-half interest owned by this corporation in 7.765 acres of land, part of original grants to Ansel McKinney, Abst. No. 218, W. R. Griffith, Abst. No. 135, and E. Ray, Assignee of Cuadrilla Irrigation Co., Abst. No. 353, and 13.743 acres of land (in three parcels), owned by this corporation, located on the George Sutherland, Abst. No. 270, original grant. Said note shall be also secured to be paid by a chattel mortgage on all personal property owned by this corporation located on said 
parcels of land, expressly including all tools, apparatus and machinery used in connection with the gin plant located thereon. No personal property to be excepted or reserved from said chattel mortgage lien.

The said James N. Lincoln, as President of and for and in behalf of this corporation is further hereby authorized and instructed to transfer, sell and assign said promissory note together with said deed of trust lien and chattel mortgage above mentioned to The First National Bank of Goliad, as collateral to secure the payment of any and all obligations now owing by this corporation to said Bank as principal, surety, endorser, as well as all obligations this corporation may hereafter own such bank as principal, surety, endorser or any otherwise.

The said James N. Lincoln, as President of and for and in behalf of this corporation, and W.L. Lutenbacher, as Secretary of this Board of Directors and General Manager of this corporation, are each hereby authorized and empowered to borrow money from said The First National Bank of Goliad, for and in behalf of this corporation and to sign its name to any note or notes or other instruments in order to obtain a loan or loans from such bank, and any and a 11 such notes or other instruments shall be accepted as the acts and deeds of this corporation, and this corporation does hereby ratify and agrees hereby to ratify and confirm any and all such acts of said James N. Lincoln, and/or said W. L. Lutenbacher, and a copy of this resolution shall be delivered to said bank for its information and guidance.

THE STATE OF TEXAS,

COUNTY OF GOLAD.

We, James N. Lincoln, as President of The Riverdale Gin and Milling Company, and W. L. Lutenbacher, as Secretary thereof, each hereby certify the above and foregoing is a true and correct copy of a certain resolution duly passed by the Board of Directors of said corporation on the day and date set out therein, a full quorum being present and voting in favor thereof. 
Witness our hands and the seal of said corporation, this the 3 rd day of July, A.D. 1939.

James N. Lincoln, President of The Riverdale Gin and Milling Company

(CORP. SEAL)

W. L. Lutenbacher, Secretary of The Riverdale Gin and Milling Company.

THE STATE OF TEXAS,

COUNTY OF GOLIAD.

BEFORE ME, the undersigned authority, on this day personally appeared James N. Lincoln, President of The Riverdale Gin and Milling Company, and W.L. Lutenbacher, Secretary of the Riverdale Gin and Milling

Company, each known to me to be the person whose name is subscribed to the foregoing instrument, and each acknowledged to me that he executed the same for the purposes and consideration therein expressed, in the capacity therein stated.

GIVEN UNDER MY HAND AND SEAL OF OFFICE, this the $3 \mathrm{rd}$ day of $\mathrm{July}$, A.D. 1939.

(SEAL)

Walter L. Bluntzer, A Notary Public in and for Goliad County, Texas.

Filed for record July 7 th, 1939 at 3 o'clock P.M.

And duly recorded July 8th, 1939 at 3:35 o'clock P.M.

R. A. Burke Clerk,

County Court, Goliad County, Texas. 
Resolution of the Goliad Independent School District for Reversion of the Riverdale School Property to J. M. Pettus (Goliad County Independent School District, Vol. 156:415)

January 11, 1953

At a meeting of the Board of Trustees of Goliad Independent School District, of Goliad County, Texas, held on the 11 th day of January, 1954, a quorum were present, towit:

Walter Friedrichs

Dodge Barton

Herman Seidel

L. H. Von Dohlen

I. M. Henslev.

Upon motion made by L.H.VonDohlen and seconded by J.M. Hensley the following resolution was unanimously adopted, towit:

Whereas, by deed dated July 6, 1923, recorded in Vol. 48, page 329, of the Deed Records of Goliad County, Texas, J.M. Pettus conveyed to the Trustees of Riverdale Independent School District, for school purposes, a certain tract of one acre of land in the George Sutherland Survey, Abstract No. 270, in Goliad County, Texas, said deed containing a reversionary clause to the effect that should said acre of land thereafter cease to be used for school purposes then the same would revert to the grantor in said deed, his heirs or assigns, reference being hereby made to said deed and the record thereof for all pertinent purposes, and

Whereas, through mistake, no school was ever placed on the hereinabove mentioned one acre tract of land, but was placed on a certain tract of one acre of land in the George Sutherland Survey, Abstract No. 270, in Goliad County, Texas, belonging to Riverdale Gin and Milling Company and described in that certain deed from Riverdale Gin and Milling Company to 
Riverdale Independent School District, which deed is dated July 3, 1939, and is recorded in Vol. 90, page 16, of the Deed Records of Goliad County, Texas, reference to which deed and the record thereof is hereby made for all pertinent purposes, and

Whereas, after said school was placed on the last mentioned one acre tract, Riverdale Gin and Milling Company conveyed said one acre tract to Riverdale Independent School District by the aforesaid deed recorded in Vol. 90, page 16, the consideration for this conveyance being the conveyance by said School District to Riverdale Gin and Milling Company of the one acre tract described in the aforesaid deed recorded in Vol. 48, page 329, of the Deed Records of Goliad County, Texas, and in order to aid in and make possible the consumation of this transaction whereby said School District became the owner of the one acre tract on which it had placed its building, the said J. M. Pettus was required to relinquish his reversionary interest in said one acre tract described in said deed so recorded in Vol. 48, page 329, of the Deed Records of Goliad County, Texas, such relinquishment being by quitclaim deed from J. M. Pettus, et ux, the Riverdale Gin and Milling Company dated June 29, 1939, recorded in Vol. 90, page 19, of the Deed Records of Goliad County, Texas, and

Whereas, Goliad Independent School District is the successor to Riverdale Independent School District, and said Goliad Independent School District no longer uses for school purposes the said tract of one acre of land described in the aforesaid deed from Riverdale Gin and Milling Company to Riverdale Independent School District, recorded in Vol. 90, page 16, of the Deed Records of Goliad County, Texas, and in view of the above facts said J. M. Pettus is entitled to said one acre of land;

Now, therefore, be it resolved that Goliad Independent School District in consideration of the premises above set out and for the further consideration of the sum of One Dollar cash, quitclaim to said J.M. 
Pettus all right, title and interest of said Goliad Independent School District in and to said tract of one acre of land described in the aforesaid deed from Riverdale Gin and Milling Company to Riverdale Independent School District, which deed is recorded in Vol. 90, page 16, of the Deed Records of Goliad County Texas, as aforesaid; and be it further resolved that Walter Friedrichs, President of the Board of Trustees of Goliad Independent School District, and he is hereby authorized and directed to execute and deliver to said J. M. Pettus a quit claim deed whereby Goliad Independent School District quitclaims all its right, title and interest in and to this one acre of land to said J.M. Pettus. 


\section{REFERENCES CITED}

Goliad County, Texas, County Courthouse, Goliad Deed Records

$\mathrm{V}$ ol. 40

Vol. 70

Deed of Trust Records

Vol. $X$

Goliad County Independent School District Board of Trustees Records 